\title{
Financing Management: An Alternative for Increasing The Profitability of Islamic Bank
}

\author{
$1^{\text {st }}$ Irma Setyawati $^{1}, 2^{\text {nd }}$ Siti Mardiyah $^{2}$ \\ \{irma.setyawati@ubharajaya.ac.id ${ }^{1}$ \} \\ University of Bhayangkara Jakarta Raya ${ }^{1,2}$
}

\begin{abstract}
The purpose of this study was to analyze the financing management carried out by Islamic banks to increase the profitability of Islamic banks in Indonesia. Data were taken from the monthly financial statements of Islamic banks of 2009-2014 period and was analyzed with simultaneous equation regression. The results of this study suggested that in model 1, equity financing positively and significantly affects the nonperforming finance, Debt financing positively and not significantly affects the nonperforming finance. While in model 2, non-performing finance negatively and significantly affects the profit expense ratio. Non-finance income positively and not significantly affects the profit expense ratio. Thus, the company's performance reflected in the profit expense ratio, which is used to assess cost efficiency performed by Islamic banks for profit achievement is largely determined by the financing management of the bank. Cost efficiency will be achieved if Islamic bank can overcome bad financing, both in the form of debt financing and equity financing.
\end{abstract}

Keywords: Debt Financing, Equity Financing, Non-Finance Income, Non-Performing Finance, Profit Expense Ratio, Simultaneous Equation.

\section{Introduction}

A country can never be separated from the banking sector, because it is the backbone of the economy (Marotta, Miccichè, Fujiwara, Iyetomi, \& Aoyama, 2016; Setyawati, 2017). The banking sector is an important means of implementing transmission mechanism from the monetary sector to the real sector (Hélène Rey, 2016). Government of a country wants soundness of banking, because it is important for economic progress in general (Marotta et al., 2016). Banking sector requires all time supervision, because banks act as an intermediate of surplus unit to the deficit unit in increasing efficiency, reallocating and utilizing funds from the last source in the economy (Mistry \& Savani, 2015; Setyawati, 2016).

Policies implemented by the government are intended to increase welfare and eliminate financial vulnerability (Setyawati, 2018). Vulnerability occurred because of the failure of the household and banking sectors (liquidity crisis) and profits of all banking sectors sharply fell (bank crisis), so that financial vulnerability is the unfulfilled short-term liquidity resulting in fragility of the banking sector (Olweny, 2011). Financial vulnerability is influenced by an increasing failure from the banking sector so that it will reduce bank profitability (Tsomocos, 2003). Thus, economic stability and growth can be maintained.

The global crisis impacts on $80 \%$ of the banking sector, where the banking sector is one of the sectors most affected (Bremus \& Fratzscher, 2014). Almost all conventional banks are 
affected by the global crisis, however it doesn't affect the performance of Islamic bank and almost insignificant when it is compared to the conventional bank. It is because the nature of the Islamic bank which all financial transactions must be based on trade and related asset (Hidayat \& Abduh, 2012), while the sectors affected by the financial crisis are financial sectors such as money markets and Islamic banks are prohibited from carrying out business activities of money market (Rey, 2016). Nevertheless, a lot of Islamic banks can be affected by the financial crisis if the real sector is affected by the crisis, considering that Islamic banks are very close to the real sector (Hassan \& Kayed, 2011).

With the development of Islamic banking in Indonesia, with the enactment of dual banking system, the problems often faced include the profitability, asset growth, funding sources growth, distribution of funds and bank business risk (Zahra, Ascarya, \& Huda, 2018). Profitability can be determined by how much the management considers the macro and micro risks (Petria, Capraru, \& Ihnatov, 2015). At the macro level, profit is a cheap source of funds for banks in developing their business, additionally, the high profit indicates market power, especially for large-scale bank. Meanwhile, low profits can lead to agency conflicts from activities performed by the bank. High and low profits will hinder the financial intermediation function because with the large market power, banks may offer low returns for savings/deposits but charge high loan interests rates. Very low profits resulting in banks failed to attract enough capital to operate and usually occur in banks with low capitalization (Dharmendra S. Mistry \& Savani, 2015).

The competition between Islamic and conventional banking is seen in the bank's effort to attract public funds. The competition between banks is not only limited to a group of banking industries, in addition to competition between banks, banks also have to compete with nonbank institutions (Vives, 2018). Islamic banks, in addition to having to compete with other Islamic banks, must also compete with conventional banks. When competition is carried out intensively and when banks start offering more or less similar products and services, customer satisfaction will affect the bank's performance and determine its competitiveness and success (Khan \& Fasih, 2005). Thus it will affect the profitability and improve management of funds distribution. Islamic banks still have low source of third party funds, even though from year to year it experience growth. However, Islamic banks and Islamic units are only able to raise third party funds around 5\% of all third party funds in the national banking industry (Setyawati, Kartini, Rachman, \& Febrian, 2015). The causes include the lack of education carried out by Islamic banks and Sharia units on Islamic banking products/services. Other factors such as the passive attitude of the people, the complexity of the products/services offered, and influence from third parties are also obstacles to Islamic bank products/services. When viewed from the side of an Islamic commercial bank, a competitive strategy with a competitor's orientation has not been optimally implemented in extending funds collection or community financing.

On the financing side, the majority of Islamic banks channel third party funds for debt financing of $70.93 \%$, with a murabahah composition of $66.42 \%$; others $4.51 \%$, while the equity financing is only $29.07 \%$ with the mudharabah composition of $18.05 \%$; musyarakah of $11.02 \%$ (Financial Services Authority, 2017). At the beginning of the development of Islamic banks, this is possible if debt financing dominates the funds distribution in banks, because of various obstacles faced in distributing equity financing, both internal and external.

Internal constraints occur because the lack of understanding of the essence of Islamic banking, the preferred business and effort orientation, the inadequate quality and quantity of resources, the behavior of aversion to effort and aversion to risk (Zahra et al., 2018), so that Islamic banks consider financing with an equity financing system has a high risk in terms of 
losses that can occur in the period of financing and can reduce company profits because the profit sharing financing is not only sharing profit but also sharing losses, if the loss is not an error/negligence of the party given the financing.

External constraints lie in the character of the equity financing which requires a very high level of honesty from the party that receives the financing. The concept of spiritual management is used as an organizational culture in the management of Islamic organizations, which means transforming Islamic teachings sourced from the Holy Qur'an and As-Sunnah about business into organizational culture and exploring Islamic values contained in these sources, such as honesty, and trust to be applied in the management of an organization (Kahf \& Khan, 2009).

Not all customers who have received financing from Islamic banks can return it properly according to the agreed time. In reality there are always some customers for whatever reason, cannot return the financing that has been given which lead to bad debt which usually creates a risk called the credit risk or the risk of inability to pay and counterparty risk (Ahmed, 2009).

Bad debt is when a bank is truly unable to deal with the risks posed by financing, in the form of risk of loss related to the counterparty unable and unwilling to fulfill the obligation to repay the loan borrowed in full at maturity or after (Cooper \& Nikolov, 2013). Bad debt financing has a high rate of non-performing financing (NPF), which ultimately lowers the profits of Islamic banks.

The profit of Islamic banks in Indonesia still relies on more than $95 \%$ of the total profit in terms of financing (Setyawati et al., 2015). By using a measure of non-financing income divided total assets (NFI/TA) as an indicator of income diversification, NFT/TA of Islamic banks in Indonesia range from $0.3 \%-5 \%$. This illustrates that Islamic banks have begun to diversify products, although not maximally. Unlike the banking business in the Republic of Korea, non-interest income is divided by total assets (NII/TA) which has an average value of $75.4 \%$, this means that banks have diversified their products and rely on fee-based income (Sufian, 2011)

There are a lot of research on the factors that affect the profits of Islamic banks, and among these studies are using financial ratios, including liquidity management, capital, operational cost efficiency, income diversification, leverage and asset quality as determinants of the profitability of Islamic banks. Some other studies include external factors as determinants of the profitability of Islamic banks, including bank concentration, supervisory, foreign ownership and regulatory variables.

The purpose of this study is to analyze the financing management carried out by Islamic banks as one way to increase the profitability of Islamic banks in Indonesia. Current research on Islamic banks is focused more on the introduction of sharia principles, laws, regulations, developments and prospects, such as research conducted by Aggarwal \& Yousef (2000), Taylor (2003), Seibel (2008), Gupta (2009), Ismail \& Achmad Tohirin (2010), Adi (2011). Other studies revolve around the efficiency of Islamic banks compared to conventional banks, such as research conducted by Hassan (2005), Jalil \& Rahman (2010), Abdul-Majid, et al (2010), Safiullah (2010), Hanif (2011), Noor \& Ahmad (2011), Yahya, et al (2012). However, research on increasing profitability through financing management carried out by Islamic banks in Indonesia has not been done much. 


\section{Research Method}

The research was conducted by accessing the monthly financial statements for the period 2009 - 2014, from eleven Islamic banks from the financial services authority site. Data were processed using Stata version 15 software, using simultaneous equation regression analysis. Estimation model for analyzing research research data is as follows:

Table 1 and 2 shows variables that affect the increase in profitability of Islamic banks.

Table 1: Variables Used in Model 1 Regression Equations

\begin{tabular}{|l|l|l|c|}
\hline Variable & Sub Variable & Definition of Variable & Hypotheses \\
\hline Dependent Variable & & NA \\
\hline Credit Risk & $\begin{array}{l}\text { Non- } \\
\text { performing } \\
\text { finance (NPF) }\end{array}$ & $\begin{array}{l}\text { Parameters that indicate bad } \\
\text { financing. } \\
\text { Measured by dividing the amount } \\
\text { of bad financing with total } \\
\text { financing }\end{array}$ & + \\
\hline Independent Variable & $\begin{array}{l}\text { Equity } \\
\text { Manancing }\end{array}$ & $\begin{array}{l}\text { Financing with profit sharing } \\
\text { principles. Measured by dividing } \\
\text { total equity financing with total } \\
\text { financing }\end{array}$ & + \\
\hline & $\begin{array}{l}\text { Debt financing } \\
\text { (DF) }\end{array}$ & $\begin{array}{l}\text { Financing with the principle of } \\
\text { buying and selling. Measured by } \\
\text { dividing total debt financing by } \\
\text { total financing }\end{array}$ & + \\
\hline
\end{tabular}

Table 3: Variables Used in Model 2 Regression Equations

\begin{tabular}{|c|c|c|c|}
\hline Variable & Sub Variable & Definition of Variable & Hypotheses \\
\hline \multicolumn{4}{|c|}{ Dependent Variable } \\
\hline Profitability & $\begin{array}{l}\text { Profit expense } \\
\text { ratio }(\mathrm{PER})\end{array}$ & $\begin{array}{l}\text { Ratio to assess cost efficiency } \\
\text { carried out by Islamic banks to } \\
\text { achieve profit. Measured by } \\
\text { dividing net income by total costs }\end{array}$ & NA \\
\hline \multicolumn{4}{|c|}{ Independent Variable } \\
\hline \multirow[t]{2}{*}{$\begin{array}{l}\text { Financing } \\
\text { Management }\end{array}$} & $\begin{array}{l}\text { Non- } \\
\text { performing } \\
\text { finance }(\mathrm{NPF})\end{array}$ & $\begin{array}{l}\text { Parameters that indicate bad } \\
\text { financing. Measured by dividing } \\
\text { the amount of bad financing with } \\
\text { total financing }\end{array}$ & + \\
\hline & $\begin{array}{l}\text { Non-financing } \\
\text { income divided } \\
\text { total asset }\end{array}$ & $\begin{array}{l}\text { Parameters that show } \\
\text { diversification of profits. } \\
\text { Measured by dividing non- }\end{array}$ & + \\
\hline
\end{tabular}




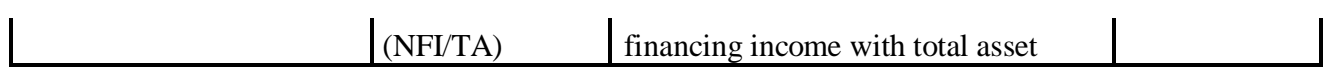

Simultaneity test can be done with the Hausman Simultaneity Test. After the model is proven to be simultaneous, the next step is the identity test with the order method to ensure that the model can be estimated, because an equation of the simultaneous system can only be estimated correctly if the equation is justly or overly identified. The order method was used in this research, if the necessary conditions have been fulfilled using the Order method, then there is enough evidence to identify simultaneous equations (Gujarati \& Porter, 2010).

For a simultaneous equations system with $M$ structural equations can be identified, then at least must have M-1 endogenous variables. If the number of endogenous variables is exactly M-1, the equation is said to be exactly identified and if the number of endogenous variables is more than $\mathrm{M}-1$, the equation is said to be over identified, or in order that a system of simultaneous equations with $M$ structural equations can be solved, the number of predetermined variables in the equation must be no less than the number of endogenous variables in the equation minus one.

\section{Result And Discussion}

The first model (1), the results of the Restricted $\mathrm{R}^{2}$, Hausman, and Langarange Multiplier tests concluded that the best data panel model was Fixed Effect. This indicates that each bank has strong individual characteristics or it can be said that the influence of independent variables (debt financing and equity financing) on dependent variable (non-performing finance) is highly dependent on individual (banks) characteristics which lead to intercept differences of each individual. While the F stat test (Global Test) states that this model is significant so that it can be accepted in describing the dependent variable.

The second model (2), the results of the Restricted $\mathrm{R}^{2}$, Hausman and Langarange Multiplier tests by the author concluded that the best data panel model was Fixed Effect. This indicated that each region has strong individual characteristics or it can be said that the influence of independent variables (non-performing finance and non-finance income) on dependent variable (profile expense ratio) is highly dependent to the individual (banks) characteristics which lead to intercept differences of each individual. While the F Stat Test (Global Test) stated that this model is significant so that it can be accepted in describing the dependent variable. Meanwhile, the estimation results of the panel simultaneous model is presented in table 2 .

Table 2. Estimation Results of Research Model: Simultaneous Model - Panel

\begin{tabular}{|c|c|c|c|c|c|}
\hline Model & & & ation & & $\mathrm{R} 2$ \\
\hline 1 & NPF & $\begin{array}{l}=-5,16^{*} \\
(105.64)\end{array}$ & $\begin{array}{l}-0,012 \mathrm{DF} \\
(0.105)\end{array}$ & $\begin{array}{l}+0,021 \mathrm{EF}^{* *} \\
(0.194)\end{array}$ & 71,98 \\
\hline 2 & PER & $\begin{array}{l}=238,27^{* *} \\
(106,33)\end{array}$ & $\begin{array}{l}-36,51 \\
\mathrm{NPF}^{* *} \\
(17,66)\end{array}$ & $\begin{array}{l}+35,36 \mathrm{NFI} \\
(26,67)\end{array}$ & 64,89 \\
\hline
\end{tabular}

*** Significant at $\alpha$ level $=1 \quad$ percent 
$* *$ Significant at $\alpha$ level $=5 \quad$ percent
$* \quad$ Significant at $\alpha$ level $=10$ percent

From model 1 it can be seen that equity financing positively and significantly affects nonperforming finance. Debt financing positively and not significantly affects non-performing finance. With R2 of $71.98 \%$, it means that the debt financing and equity financing variables are able to explain the NPF variable of $91.98 \%$, while $28.02 \%$ is explained by other variables outside the model. Equity financing is a financing transaction for a cooperation aimed at obtaining both goods and services, with the principle of profit sharing. The profit-sharing product is determined by the agreed profit sharing ratio in advance. Banking products included in this group are musyarakah and mudharabah.

Musyarakah is a partnership agreement between two or more parties for a particular business where each party contributes funds (or charity/expertise) with an agreement that the benefits and risks will be borne together in accordance with the agreement. The profit sharing system (musyarakah) requires complex calculations, especially in calculating the profit portion of small customers whose savings value in the bank is not fixed. Thus the possibility of miscalculating can occur at any time.

Mudharabah is a contract of business cooperation between two parties where the first party (Shahibul Maal) provides all $(100 \%)$ capital, while the other party becomes the manager. Mudharabah business profits are divided according to the contract agreement, whereas the loss is borne by the capital owner as long as the loss is not due to the negligence of the manager. Mudharabah also has risks such as side streaming; the customer uses the funds not as stated in the contract; negligent and intentional mistakes and concealment of profits by the customer, if the customer is not honest. Thus, equity financing causes Islamic banks to receive a share of profit sharing from the financing in small amounts or even can suffer losses.

Debt financing is a financing transaction aimed at owning goods with the principle of buying and selling. Products included in this group are products that use the principle of debt financing, namely murabahah, salam, istishna, ijarah, qard.

Murabahah is a buying and selling transaction where the bank calls the amount of profit. The bank acts as a seller, while the customer as a buyer. Both parties must agree on the selling price and payment term. In banking, murabahah is usually carried out by installment payments (bi tsaman ajil). In this transaction the goods are delivered immediately after the contract while the payment is made in a delayed manner.

Salam is a buying and selling transaction where the goods being sold is not ready yet. Therefore, goods are delivered in a delayed manner while payments are made in cash. The bank acts as a buyer, while the customer acts as a seller. In practice, when the item has been handed over to the bank, the bank will sell it to the customer or customer partner itself in cash or in installments. The selling price set by the bank is the bank's purchase price from the customer plus profit. In the case of banks selling it in cash it is usually called bridging financing. Whereas if the bank sells it in installments, both parties must agree on the selling price and the term of payment. The selling price is included in the sale and purchase contract and if agreed upon it cannot change during the validity of the contract. Generally this transaction is applied in financing goods that do not ready yet, such as purchasing agricultural commodities by the bank and then reselling them in cash or in installments.

Istishna products resemble Salam products, but in Istishna the payment can be made by the bank several times (terms) of payment. The Istishna scheme in Islamic banks is generally applied to manufacturing and construction financing. 
The ijarah transaction is based on the transfer of benefits. So basically the principle of ijarah is similar to the principle of buying and selling, but the difference lies in the object of the transaction. The object of the transaction in selling - buying is goods, while object of the transaction in ijarah is service. At the end of the lease period, the Bank may sell the goods it rent to customers. Therefore in Islamic banking there is a term ijarah muntahiyyah bittamlik (rent followed by transfer of ownership). The rental price and selling price are agreed at the beginning of the agreement.

Qardh is the giving of assets to other people who can be billed or asked to return or in other words lend without expecting a reward.

Thus, debt financing has risks such as default or negligence; customers intentionally do not pay the installments, comparative price fluctuations; this happens when the price of an item in the market rises after the bank buys it for the customer. The bank cannot change the sale and purchase price, customer refusal; goods that have been sent may be rejected by the customer, sold; Customers are free to sell their assets so there will be larger risk for default. While qardh is risky because it considered a financing that is not covered by collateral.

In model 2, it can be seen that non-performing finance negatively and significantly affects the profit expense ratio. Non-finance income has positive insignificant effect on profit expense ratio. With R2 of $64.89 \%$, it means that the NPF and NFI variables are able to explain the profit expense ratio variable of $64.89 \%$, while $35.11 \%$ is explained by other variables outside the model.

Non-performing financing is the ratio between bad financing and the total financing disbursed by Islamic banks. Based on the criteria set by the Bank of Indonesia, those categorized in NPF are substandard, doubtful and loss financing. Not all customers who have received funding from the bank are able to return the fund properly according to the agreed time, in fact there are always some customers that cannot return the loans that have been given for whatever reasons, which leads to bad financing. Bad financing is a condition in which a customer is unable to pay the full amount of financing the bank gives on time, resulting in bad financing. Usually it will cause a risk called credit risk or the risk of inability to pay and counterparty risk (Sufian, 2010).

Non-performing financing (NPF) will impact on the decreasing level of profit sharing shared with fund owners. The relationship between banks and customers is based on two interrelated elements, namely law and trust. A bank can only carry out activities and develop its business if the customer believes to place the money. Then after collecting funds from the community in the form of deposits, the bank then channeled back to the community in order to improve people's living standards (Setyawati et al., 2015). Without immediate steps taken regarding the bad credit in a relatively large amount or even incorrect information regarding bad credit experienced by a particular bank, it will cause anxiety to the bank's customers and may lead to a bank rush (Hassan \& Kayed, 2011). The ideal non-performing financing (NPF) value is in accordance with the regulations of the Bank of Indonesia with a maximum of $5 \%$ in accordance with the regulations of the Bank of Indonesia Number 15/2/PBI/2013 concerning Determination of Status and Follow-Up for Commercial Bank Supervision.

Non-finance income is the income of a bank outside the interest income/profit sharing proceeds from non-traditional activities, to measure diversification of income from nontraditional activities. Non-financing income includes commissions, services, fees, guarantee fees, net income from the sale of securities and net income from the sale of foreign exchange (Sufian \& Habibullah, 2010). In his research, used the NII/TA (non-interest divided income by total assets) ratio to measure bank diversification against traditional funding sources. The increasing non-financing income (fee based) is expected to increase profits. If there is an 
expectation of increasing income from non-financing, then the bank's business shifts from traditional intermediaries, which will reduce income from financing and simultaneously will reduce bad financing and financing risk (Jalil \& Rahman, 2010).

The increase in NPF is due to the accumulation of several problems. First, global financial conditions not only reduce aggregate demand, but also cause Islamic banks to be in an increasingly fierce competitive climate. This situation makes Islamic banks difficult to maintain the market and reduce the business prospects. As a result, the income of Islamic banks declined with unhealthy balance sheet. This makes the ability of Islamic banks to pay in the form of profit sharing to customers or pay obligations from issued Sharia bonds to decrease. Second, the banking policy of maintaining high profit sharing amidst unstable economic conditions also contributed to the rise of the NFF. The high profit sharing when the company's income and balance sheet (mudarib) decrease, makes the installment burden of the company's financing to the banking sector relatively increased. Third, banking inadvertence in channeling financing is also likely to encourage an increase in NPF. When banks maintain a high profit share, banks are in fact in the possibility of increasing the risk of bad financing. When profit sharing remains high, only risk taker companies will propose financing requests to Islamic banks. Fourth, as a monetary authority, BI must also be responsible for the NPF incrase. Some of BI's policies to relax the financing distribution process, such as the type and quality of collateral or a decrease in the minimum reserve requirement (GWM), which is expected to increase the role of bank intermediation, seem to have a detrimental effect on the NPF increase.

\section{Conclusion}

From models 1 and 2 it can be seen that the company's performance reflected in the profit expense ratio, which is used to assess the cost efficiency carried out by Islamic banks for profit achievement is largely determined by the bank's financing management. Cost efficiency will be achieved if Islamic banks can overcome bad financing, both in the form of debt financing and equity financing. In addition, Islamic banks must maximize the income that comes from financing, but non-financing income, such as bank services.

However, the NPF increase will force banks to strengthen their capital structure. For this purpose, banks may enlarge the allowance for earning assets (PPAP). The consequence is that when banks try to strengthen the capital structure, this will automatically reduce the ability of banks to expand to the financing sector (to the real sector).

Reducing Islamic banking capacity to expand to financing sector will have a negative impact on the economy, because the negative impact of the global economy has decrease the role of several capital sources to support economic growth such as portfolio investment in the capital market, FDI and private capital. Thus, only state expenditure and bank financing that can still be expected as a source of capital to encourage economic growth. Therefore, the financing management of Islamic bank is needed to ensure the stability of the Indonesian economy. By managing the funds that are channeled to the community well, it will encourage economic growth and improve people's welfare.

In this regard, banks should improve stricter control management in carrying out the process of selection and verification of prospective debtors to assess collateral and business prospects, disbursement of financing, monitoring, and collecting refunds. Efforts to reduce the 
high NPF must be a concern of all parties. If not, the NPF will become an obstacle to achieve the economic growth.

\section{References}

[1]. Ahmed, H. (2009). Financial Crisis : Risks And Lessons For Islamic Finance. Isra International Journal Of Islamic Finance, 1(1), 7-32. Retrieved From Http://Kantakji.Com/Media/7513/C47.Pdf

[2]. Bremus, F., \& Fratzscher, M. W. (2014). Drivers Of Structural Change In Cross-Border Banking Since The Global Financial Crisis.

[3]. Cooper, R., \& Nikolov, K. (2013). Government Debt And Banking Fragility: The Spreading Of Strategic Uncertainty.

[4]. Dharmendra S. Mistry, \& Savani, V. (2015). A Comparative Study Of The Profitabiliity Performance In The Banking Sector: Evidence From Indian Private Sector Bank. Xvi Annual Conference Proceedings, (978), 346-360.

[5]. Financial Services Authority. (2017). Statistic Of Indonesian Capital Market 2017.

[6]. Gujarati, D. N., \& Porter, D. C. (2010). Essentials Of Econometrics.

[7]. Hassan, M. K., \& Kayed, R. (2011). The Global Financial Crisis And Islamic Finance. Thunderbird International Business Review. Https://Doi.Org/10.1002/Tie.20434

[8]. Hélène Rey. (2016). International Channels Of Transmission Of Monetary Policy And The Mundellian Trilemma.

[9]. Hidayat, S. E., \& Abduh, M. (2012). Does Financial Crisis Give Impacts On Bahrain Islamic Banking Performance? A Panel Regression Analysis. International Journal Of Economics \& Finance, 4(7), 79-89. Https://Doi.Org/10.5539/Ijef

[10]. Jalil, A., \& Rahman, M. K. (2010). Financial Transactions In Islamic Banking Are Viable Alternatives To The Conventional Banking Transactions. International Journal Of Business And Social Science, 1(3), 220-234.

[11]. Kahf, M., \& Khan, T. (2009). Principles Of Islamic Finance. In Islamic Research And Trainning Institute (P. 1083).

[12]. Khan, M. M., \& Fasih, M. (2005). Impact Of Service Quality On Customer Satisfaction And Customer Loyalty: Evidence From Banking Sector. Pakistan Journal Of Commerce And Social Sciences, 15(2), 479-485. Https://Doi.Org/Http://Dx.Doi.Org/10.1007/978-4-431-56472-0_17

[13]. Marotta, L., Miccichè, S., Fujiwara, Y., Iyetomi, H., \& Aoyama, H. (2016). Backbone Of Credit Relationships In The Japanese Credit Market. Epj Data Sci., 5(10), 1-14. Https://Doi.Org/10.1140/Epjds/S13688-016-0071-7

[14]. Mistry, D. S., \& Savani, V. (2015). A Comparative Study Of The Profitability Performance In The Banking Sector: Evidence From Indian Private Sector Bank.

[15]. Olweny, T. (2011). Effects Of Banking Sectoral Factors On The Profitability Of Commercial Banks In Kenya. Economics And Finance Review, 1(5), 1-30. Retrieved From Http://Wwww.Businessjournalz.Org/Efr

[16]. Petria, N., Capraru, B., \& Ihnatov, I. (2015). Determinants Of Banks' Profitability: Evidence From $\mathrm{Eu} 27$ Banking Systems. Procedia Economics And Finance, 20(15), 518-524. Https://Doi.Org/10.1016/S2212-5671(15)00104-5

[17]. Rey, H. (2016). International Channels Of Transmission Of Monetary Policy And The Mundellian Trilemma. Ммит.

[18]. Setyawati, I. (2016). Determinants Of Growth And Profitability By Bank Specific Variable And Market Structure In Islamic Banking In Indonesia. Academy Of Strategic Management Journal, 15(3), 1-14.

[19]. Setyawati, I. (2017). Did The Bank With Bigger Of Total Assets Had Ensured Its Financial Soundness? In Iciebp (Pp. 169-175).

[20]. Setyawati, I. (2018). Global Financial Crisis 2008 And Its Vulnerability In Saarc Countries. Busness And Economic Horizons, 14(4), 766-776. 
[21]. Setyawati, I., Kartini, D., Rachman, S., \& Febrian, E. (2015). Assessing The Islamic Banking Financial Performance In Indonesia. International Journal Of Education And Research, 3(10), 233248. Retrieved From Http://Www.Ijern.Com/Journal/2015/October-2015/19.Pdf

[22]. Sufian, F. (2010). Financial Depression And The Profitability Of The Banking Sector Of The Republic Of Korea : Panel Evidence On Bank-Specific And. Asia-Pacific Development Journal, $17(2), 65-92$.

[23]. Sufian, F. (2011). Profitability Of The Korean Banking Sector: Panel Evidence On Bank-Specific And Macroeconomic Determinants. Journal Of Economics And Management), 7(1), 43-72.

[24]. Sufian, F., \& Habibullah, M. S. (2010). Assessing The Impact Of Financial Crisis On Bank Performance Empirical Evidence From Indonesia. Asean Economic Bulletin Vot, 27(3), 245-62. Https://Doi.Org/10.1355/Ae27-3a

[25]. Tsomocos, D. P. (2003). Equilibrium Analysis , Banking, Contagion And Financial Fragility (No. 175). London. Retrieved From Http://Eprints.Lse.Ac.Uk/24826/1/Dp450.Pdf

[26]. Vives, X. (2018). Competition And Stability In Modern Banking: A Post-Crisis Perspective.

[27]. Zahra, S. F., Ascarya, A., \& Huda, N. (2018). Stability Measurement Of Dual Banking System In Indonesia: Markov Switching Approach. Al-Iqtishad: Jurnal Ilmu Ekonomi Syariah, 10(1). Https://Doi.Org/10.15408/Aiq.V10i1.5867 